\title{
Predation on naked protozoan microzooplankton by fish larvae
}

\author{
Kimio Fukami ${ }^{1, *}$, Aki Watanabe ${ }^{1}$, Shinji Fujita $^{2}$, Kosaku Yamaoka $^{3}$, Toshitaka Nishijima ${ }^{1}$ \\ ${ }^{1}$ Laboratory of Aquatic Environmental Science (LAQUES), Kochi University, Nankoku, Kochi 783-8502, Japan \\ ${ }^{2}$ Nishinihon Institute of Technology, Wakamatsu-cho, Kochi 780-0812, Japan \\ ${ }^{3}$ Usa Marine Biological Institute, Kochi University, Tosa, Kochi 781-1164, Japan
}

\begin{abstract}
To evaluate the role of fish larvae as a link between the microbial loop and higher trophic levels, predation of protozoan zooplankton by young larvae was investigated. More than 400 individual fish larvae with total lengths of less than ca $10 \mathrm{~mm}$ in 52 different taxonomic groups were collected at different sampling times from several coastal regions, and the gut contents of larvae were examined under epifluorescence microscopy after staining with DAPI. Among numerous fragments of copepod nauplii, many flagellate-like cells with a size of $5 \mu \mathrm{m}$ and ciliate-like cells with a size of 20 to $30 \mu \mathrm{m}$ were frequently recognized. The number of protozoan cells varied significantly from one larva to another. Some individuals had more than 60 protozoa, while others contained none at all. The amount of protists contained in the gut of larvae depended on the fish species and did not show any trend with the body or mouth sizes of larvae, nor the sampling site or season. Fish taxa were divided into 3 groups depending on the amount of protists in the gut: 'abundant', 'moderate', and 'none' The Acanthopterygii group contained the highest concentration of protozod. Results of the present study suggested that fish larvae of some taxonomical groups were important predators of protozoa and may be an important link between the microbial loop and the grazing food chain.
\end{abstract}

KEY WORDS: Protozoa P Predation - Diet of fish larvae - Microbial loop - Grazing food chain - Gut content

\section{INTRODUCTION}

Heterotrophic flagellates and ciliates are widely distributed in aquatic environments (see Porter et al. 1985, Fenchel 1986 for a review). They are the main consumers of microbes and play an important role in the energy flow of aquatic ecosystems (Fenchel 1982, Azam et al. 1983, Hagström et al. 1988, Sherr \& Sherr 1988, Fukami et al. 1991, 1996). Many reports have been published on the bacterivory of protozoa. However, much uncertainty still remains on the carbon transfer from the microbial loop to higher trophic levels (Sherr et al. 1986). Sherr et al. (1986) pointed out that the predation on protozoa by metazoa could be a 'missing' trophic link in marine pelagic food webs. Some recent studies indicate that flagellates and ciliates are important in the diet of metazoans such ds calanoid

\footnotetext{
•E-mail: fukami@cc.kochi-u.ac.jp
}

copepods and/or cladocerans in marine and freshwater environments (Stoecker et al. 1987a,b, Sherr \& Sherr 1988, Turner et al. 1988, Stoecker \& Capuzzo 1990, Hartmann et al. 1993). However, the fate of bacterivorous protozoans is not yet well known.

Protozoa may also be consumed by fish larvae. Considerable information exists on the diet of fish larvae (see Tanaka 1980 for a review). Last (1978a, b) reported that most diets of flat fish larvae of several species consisted of nauplii and copepodites of calanoid copepods, although some diatoms, dinoflagellates and tintinnids were also present. The main diets of some menhaden (Govoni et al. 1983, Stoecker \& Govoni 1984), Atlantic croaker (Govoni et al. 1983) and Japanese sardine (Nakata 1988) larvae consisted of copepod nauplii. The diets of Japanese flounder larvae were Oikopleura spp. and copepod nauplii (Ikewaki \& Tanaka 1993). So far, it has generally been considered that fish larvae feed mostly on copepod nauplii and sometimes on loricate tintinnid ciliates. 
However, copepod nauplii are too large for young larvae with body lengths of less than 2 to $3 \mathrm{~mm}$ to consume (Lasker et al. 1970, Last 1978a, b, Ikewaki \& Tanaka 1993). The proportion of tintinnids in gut contents tends, therefore, to increase with decreasing size of fish larvae (Last 1978a,b, Stoecker \& Govoni 1984). The biomass of protozoa is on the same order of magnitude as that of copepod nauplii (Uye et al. 1996. 1998, Uye \& Shimazu 1997). Moreover, as the growth and turnover rates of protozoa are much faster than those of copepods, the contribution of protists to the diet of higher trophic level consumers should be much larger. Since protozoa move more slowly than most copepod nauplii, they should be easily caught by young larval fish (Stoecker \&

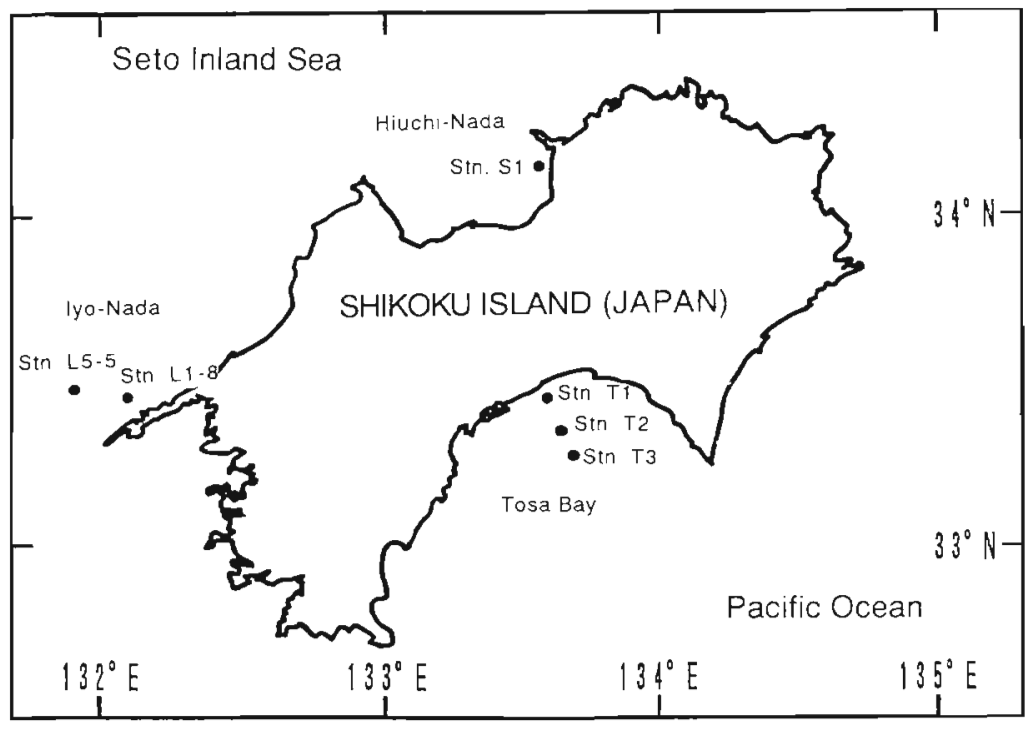

Fig. 1. Sampling sites $(\bullet)$ around Shikoku island, Japan

Govoni 1984). The majority of planktonic protozoa are non-loricate, fragile species and, therefore, are easily decomposed in the fish gut. Thus, protist ingestion may have been neglected in the past because of difficulties in describing the gut contents of fish larvae, due to a high degree of decompositon of the food and the use of normal techniques of microscopy for species identification. Modern fluorescence microscopy approaches have not yet been used in this specific research field.

In the present study, we collected many fish larvae covering a wide range of taxa in the natural environment and observed carefully the gut contents by using epifluorescence microscopy and the DAPI-staining method. Results obtained in this study supported the contention that fish larvae may be a link between the microbial loop and higher trophic levels.

\section{MATERIALS AND METHODS}

Sample collection. Samples of fish larvae were collected from surface (Stns T1-0, T2-0, T3-0, Fig. 1) and 0 to $30 \mathrm{~m}$ depth (Stn T2-30, Fig. 1) waters of Tosa Bay by oblique tows using a conical plankton net, with a mouth diameter of $1 \mathrm{~m}$ and mesh size of $0.33 \mathrm{~mm}$, on 12 occasions from April 1993 through March 1994. Sample collections were also carried out in Iyo-Nada ( 0 to $42 \mathrm{~m}$ at Stn L1-8, 0 to $51 \mathrm{~m}$ at L5-5, Fig. 1) on June 30 and July 1, 1993, respectively, and from surface water in western Hiuchi-Nada (Stn S1, Fig. 1) in August 1994, using the same plankton net.

Larval samples were fixed immediately on board with $2 \%$ formalin neutralized with hexamethylenetetramine, or were brought back to the laboratory in ice-cold condition and then fixed in the laboratory as described above. All the larval samples fixed were maintained in the cold $\left(4^{\circ} \mathrm{C}\right)$ for up to 2 wk until analysis.

Seawater samples were collected at the same station as the larvae, and were fixed with glutaraldehyde (final conc. $1 \%$ ). These samples were used for counting the abundances of protists in seawater.

Laboratory analyses. Individuals of post larval stage were selected. After identifying the taxonomical group of the fish samples, total length (TL) and upper jaw length (UJL) were measured.

The whole alimentary canal of each individual larva was removed by using a sharp operating needle under binocular microscopy. The needle was prepared with tungsten wire (diam. $0.4 \mathrm{~mm}$ ) after sharpening the tip by melting the point in sodium nitrite in a crucible. After several rinsings with filtered seawater on the glass slide, the gut was opened with a needle, and all contents were removed and placed into $1 \%$ glutaraldehyde in the well of a microplate. They were kept in a refrigerator for up to $3 \mathrm{~d}$ until observation.

The gut contents were double-stained; first by fluorescein isothiocyanate (FITC) (final conc. 2 to $4 \mu \mathrm{g}$ $\mathrm{ml}^{-1}$ ) for $5 \mathrm{~min}$ and subsequently by 4,6-diamidino-2phenylindole (DAPI) (final conc. $0.1 \mu \mathrm{g} \mathrm{ml}{ }^{\mathrm{t}}$ ) for $5 \mathrm{~min}$ (Porter \& Feig 1980, Imai \& Ito 1984). All the samples in a microplate well were then filtered onto a $1.0 \mu \mathrm{m}$ Nuclepore filter pre-stained with Sudan Black B (Fukami et al. 1991). Protozoa with DAPI-stained clear nuclei in the gut contents were counted using an epifluorescence microscope equipped with filter sets for IB (excitation filter BP460-490, dichroic mirror DM505, absorbing filter BA515F) and UV (excitation filter BP330-385, dichroic mirror DM400, absorbing filter BA420) excitation. 


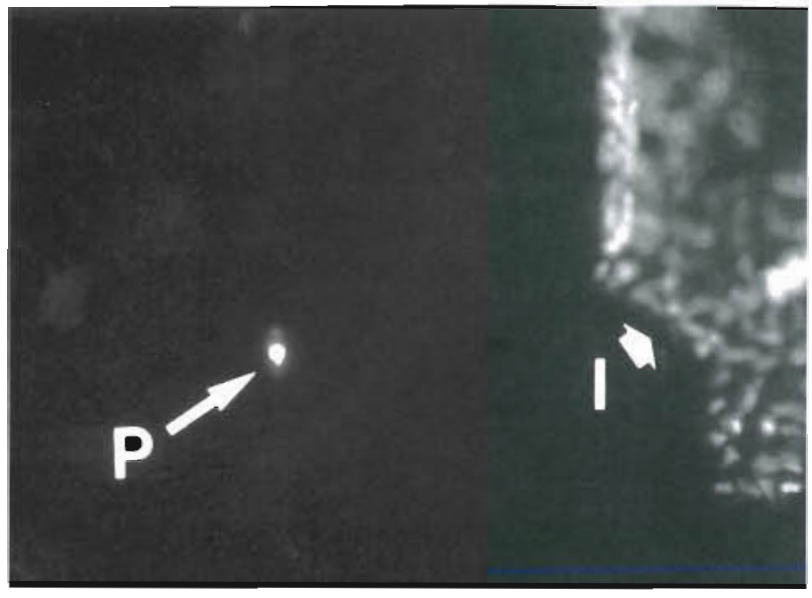

Fig. 2. Cell clump detached from trunks of fish intestine (I) and small protozoan (ciliate) cell in the gut (P)

During the mic roscopic observation, it was sometimes difficult at first to differentiate protozoa and cells detached from trunks of fish intestine (Nakata 1988). However, we noticed later that the latter was usually observed in clumps of several intact cells of similar size and morphology (Fig. 2), while the former was always a single, unattached cell (Figs. 2 \& 3). Therefore protozoan cells and gut cells could be distinguished from each other

\section{RESULTS}

We examined the gut contents of 434 individuals, in at least 52 different genera, of fish larvae, from 3 different areas (Fig. 1). Total lengths of most larvae examined were less than $10 \mathrm{~mm}$, and usually only several millimeters (Tables $1 \& 2$ ).

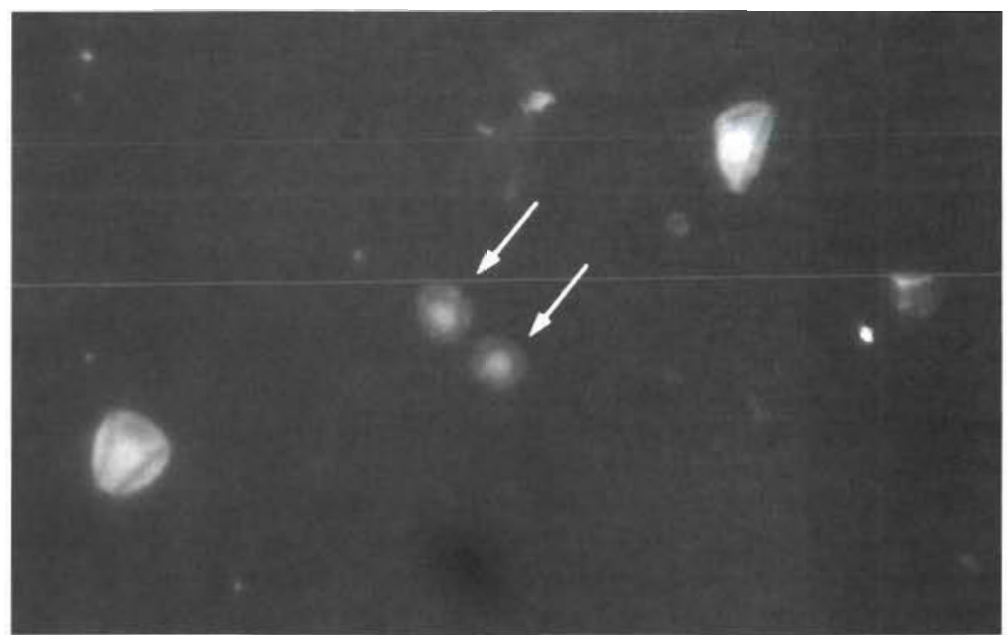

Fig. 3. Protozoan zooplankton cells (arrows) observed in the gut contents of fish larvae under epifluorescence microscopy. Diameters are about $10 \mu \mathrm{m}$
Table 1. Terapon jarbua. Individuals examined. Date and stations of sample collection, total length (TL), upper jaw length (UJL), and amount of protozoan-like cells in the gut content (no. of protists) are shown. 0 : no protists observed; + : containing less than 30 protists ++ : containing between 30 and 60 protists, +++ : containing more than 60 protists. ND: not determined

\begin{tabular}{|c|c|c|c|c|}
\hline $\begin{array}{l}\text { Sampling } \\
\text { date (1993) }\end{array}$ & Stn depth & $\begin{array}{c}\mathrm{TL} \\
(\mathrm{mm})\end{array}$ & $\begin{array}{l}\text { UJL } \\
\text { (mm) }\end{array}$ & $\begin{array}{l}\text { No. of } \\
\text { protist }\end{array}$ \\
\hline \multirow[t]{7}{*}{ Aug 18} & \multirow[t]{4}{*}{ T1-0 } & 3.70 & 1.00 & 0 \\
\hline & & 8.60 & 0.70 & 0 \\
\hline & & 10.95 & 0.85 & + \\
\hline & & 11.45 & 0.90 & 0 \\
\hline & \multirow[t]{2}{*}{ T2-0 } & 6.65 & 0.70 & + \\
\hline & & 6.80 & 0.70 & + \\
\hline & T3-0 & 6.05 & 0.45 & + \\
\hline \multirow[t]{13}{*}{ Sep 20} & & 5.75 & 0.30 & + \\
\hline & \multirow[t]{12}{*}{ T3-0 } & 3.10 & ND & + \\
\hline & & 3.35 & 0.15 & + \\
\hline & & 3.55 & 0.20 & + \\
\hline & & 3.55 & 0.20 & + \\
\hline & & 3.80 & 0.30 & + \\
\hline & & 4.05 & 0.35 & + \\
\hline & & 5.45 & 0.35 & + \\
\hline & & 5.50 & 0.40 & ++ \\
\hline & & 5.70 & 0.35 & +t \\
\hline & & 5.90 & 0.40 & + \\
\hline & & 6.45 & 0.40 & + \\
\hline & & 6.65 & 0.40 & + \\
\hline \multirow[t]{9}{*}{ Oct 22} & \multirow[t]{4}{*}{$\mathrm{T} 1-0$} & 4.05 & 0.30 & 0 \\
\hline & & 6.40 & 0.40 & + \\
\hline & & 6.95 & 0.50 & + \\
\hline & & 7.80 & 0.35 & + \\
\hline & \multirow[t]{3}{*}{$\mathrm{T} 2-0$} & 4.50 & 0.30 & + \\
\hline & & 4.55 & 0.30 & + \\
\hline & & 4.60 & 0.30 & + \\
\hline & \multirow[t]{2}{*}{$\mathrm{T} 2-30$} & 5.80 & 0.30 & ++ \\
\hline & & 5.85 & 0.50 & + \\
\hline Nov 16 & T2-0 & 6.05 & 0.30 & + \\
\hline
\end{tabular}

Numerous fragments of copepod nauplii as well as phytoplankton cells were observed in most guts. Many flagellatelike cells with a size of ca $5 \mu \mathrm{m}$ and ciliate-like cells with a size of 20 to $30 \mu \mathrm{m}$ were frequently recognized (Fig. 3), although these protozoa were not identified taxonomically, as some protozoan cells, especially the ciliate-like cells, were partly decomposed.

Since the numbers of protozoan-like cells in 1 fish larva varied significantly from one individual to another, we divided the fish larvae into 4 groups according to the number of protozoa contained in the gut: Group 0 , for no protozoa observed at all; Group +, containing less than 30 cells; Group ++, con- 
Table 2. List of taxonomical names of fish larvae examined, numbers of individuals observed, total length (TL), upper jaw length (UJL), and numbers of larvae in 4 categories with different amounts of protists in the gut. 0 : no protists observed; + : containing less than 30 protist $s_{i}++$ : containing between 30 and 60 protists $;+++$ containing more than 60 protists. ND: not determined

\begin{tabular}{|c|c|c|c|c|c|c|c|}
\hline \multirow[t]{2}{*}{ Taxon } & \multirow{2}{*}{$\begin{array}{c}\text { No of } \\
\text { individuals }\end{array}$} & \multirow{2}{*}{$\begin{array}{c}\mathrm{TL} \\
(\mathrm{mm})\end{array}$} & \multirow{2}{*}{$\begin{array}{c}\mathrm{UJL} \\
(\mathrm{mm})\end{array}$} & \multicolumn{4}{|c|}{ No. of protists in the gut } \\
\hline & & & & 0 & + & ++ & +++ \\
\hline Engraulis japonicus & 23 & $6.95-14.60$ & ND & 23 & 0 & 0 & 0 \\
\hline Etrumeus teres & 2 & $6.00-7.20$ & 0.25 & 0 & 2 & 0 & 0 \\
\hline Sardinella zunasi & 1 & 5.70 & 0.20 & 1 & 0 & 0 & 0 \\
\hline Sardinops melanostictus & 89 & $5.35-15.35$ & $0.15-0.60$ & 89 & 0 & 0 & 0 \\
\hline Saurida sp. & 2 & $4.35-6.05$ & $0.15-0.35$ & 1 & 1 & 0 & 0 \\
\hline Myctophidae spp. & 4 & $4.15-7.65$ & $0.30-0.50$ & 2 & 2 & 0 & 0 \\
\hline Ophidiidae sp. & 1 & 6.05 & 0.20 & 1 & 0 & 0 & 0 \\
\hline Laemonema nana & 3 & $4.10-8.20$ & $0.35-0.80$ & 1 & 0 & 1 & 1 \\
\hline Bregmacerotidae sp. & 5 & $4.20-7.80$ & $0.55-0.80$ & 2 & 3 & 0 & 0 \\
\hline Chelon sp. & 12 & $4.40-8.20$ & $0.25-0.40$ & 0 & 6 & 6 & 0 \\
\hline Mugil cephalus cephalus & 1 & 3.80 & 0.20 & 0 & 1 & 0 & 0 \\
\hline Atherinidae sp. & 1 & 5.95 & 0.15 & 1 & 0 & 0 & 0 \\
\hline Cololabis saira & 4 & $5.20-7.05$ & $0.20-0.25$ & 0 & 4 & 0 & 0 \\
\hline Exocoetidae spp. & 14 & $4.10-8.80$ & $0.20-0.40$ & 2 & 9 & 2 & 1 \\
\hline Macroramphosus scolopax & 3 & $3.35-5.25$ & $0.15-0.20$ & 1 & 2 & 0 & 0 \\
\hline Scorpaenidae spp. & 13 & $2.50-4.80$ & $0.15-0.40$ & 0 & 13 & 0 & 0 \\
\hline Sebastiscus marmoratus & 2 & $4.10-6.20$ & $0.20-0.40$ & 0 & 2 & 0 & 0 \\
\hline Platycephalidae sp. & 2 & $4.65-5.50$ & $0.70-0.75$ & 1 & 1 & 0 & 0 \\
\hline Sacura margaritacea & 1 & 4.60 & 0.80 & 0 & 1 & 0 & 0 \\
\hline Sillago japonica & 11 & $3.00-8.25$ & $0.20-0.65$ & 6 & 5 & 0 & 0 \\
\hline Carangidae spp. & 24 & $3.10-9.80$ & $0.20-0.70$ & 4 & 18 & 2 & 0 \\
\hline Seriola sp. & 1 & 7.00 & 0.80 & 0 & 0 & 1 & 0 \\
\hline Trachurus japonicus & 1 & 6.80 & ND & 0 & 1 & 0 & 0 \\
\hline Gerres oyend & 6 & $10.20-11.60$ & $0.80-1.00$ & 6 & 0 & 0 & 0 \\
\hline Acanthopagrus schlegeli & 1 & 4.30 & 0.20 & 0 & 1 & 0 & 0 \\
\hline Sparus sarba & 1 & 11.55 & 0.40 & 0 & 0 & 1 & 0 \\
\hline Sciaenidae sp. & 1 & 4.95 & 0.40 & 0 & 0 & 1 & 0 \\
\hline Mullidae spp. & 40 & $3.60-8.95$ & $0.25-0.75$ & 4 & 30 & 6 & 0 \\
\hline Girella spp. & 13 & $4.50-9.70$ & $0.20-0.45$ & 3 & 8 & 2 & 0 \\
\hline Microcanthus strigatus & 1 & 8.80 & 0.40 & 0 & 0 & 1 & 0 \\
\hline Terapontidae sp. & 2 & $4.10-4.35$ & $0.20-0.30$ & 0 & 2 & 0 & 0 \\
\hline Terapon jarbua & 30 & $3.10-11.45$ & $0.30-0.90$ & 4 & 23 & 3 & 0 \\
\hline Pomacentridae sp. & 1 & 3.80 & 0.40 & 0 & 0 & 1 & 0 \\
\hline Chromis notata notata & 10 & $2.15-2.40$ & 0.15 & 0 & 10 & 0 & 0 \\
\hline Labridae spp. & 9 & $3.50-7.40$ & $0.20-0.35$ & 7 & 2 & 0 & 0 \\
\hline Champsodon snyderi & 2 & $4.60-4.65$ & $0.30-0.40$ & 0 & 2 & 0 & 0 \\
\hline Pinguipedidae sp. & 1 & 3.80 & 0.20 & 1 & 0 & 0 & 0 \\
\hline Trichonotidae sp. & 1 & 10.00 & 0.40 & 1 & 0 & 0 & 0 \\
\hline Enneapterygius etheostomus & 1 & 3.65 & 0.25 & 0 & 1 & 0 & 0 \\
\hline Blenniidae spp. & 29 & $3.00-11.10$ & $0.20-0.50$ & 4 & 23 & 2 & 0 \\
\hline Parablennius yatabei & 8 & $4.40-9.90$ & $0.20-0.40$ & 0 & 3 & 4 & 1 \\
\hline Callionymidae spp. & 19 & $2.20-7.35$ & $0.15-0.30$ & 0 & 14 & 2 & 3 \\
\hline Gobiidae spp. & 13 & $2.10-7.65$ & $0.15-0.35$ & 3 & 10 & 0 & 0 \\
\hline Sphyraena sp. & 2 & $15.20-17.50$ & $2.30-2.65$ & 0 & 2 & 0 & 0 \\
\hline Sphyraena pinguis & 1 & 5.40 & 0.80 & 1 & 0 & 0 & 0 \\
\hline Trichiurus japonicus & 3 & $6.15-8.25$ & 0.70 & 2 & 1 & 0 & 0 \\
\hline Scomber japonicus & 7 & $4.00-7.20$ & $0.20-0.70$ & 2 & 3 & 1 & 1 \\
\hline Bothidae sp. & 1 & 6.00 & 0.25 & 0 & 1 & 0 & 0 \\
\hline Cynoglossidae sp. & 2 & 5.05 & $0.20-0.25$ & 1 & 1. & 0 & 0 \\
\hline Cynoglossus sp. & 1 & 6.75 & 0.60 & 0 & 1 & 0 & 0 \\
\hline Rudarius ercodes & 3 & $5.55-7.10$ & 0.30 & 0 & 0 & 2 & 1 \\
\hline Stephanolepis cirrhifer & 5 & $3.80-5.80$ & $0.25-0.40$ & 0 & 1 & 2 & 2 \\
\hline
\end{tabular}

taining between 30 and 60 cells; and Group +++ , containing more than 60 cells. In this classification, the amount of other food, i.e. copepod nauplii, was not taken into account.
The results for Terapon jarbua are shown in Table 1 as a representative example. Most larvae of this species had many protozoan cells in the gut. The maximum contribution of protozoa to the gut contents in 


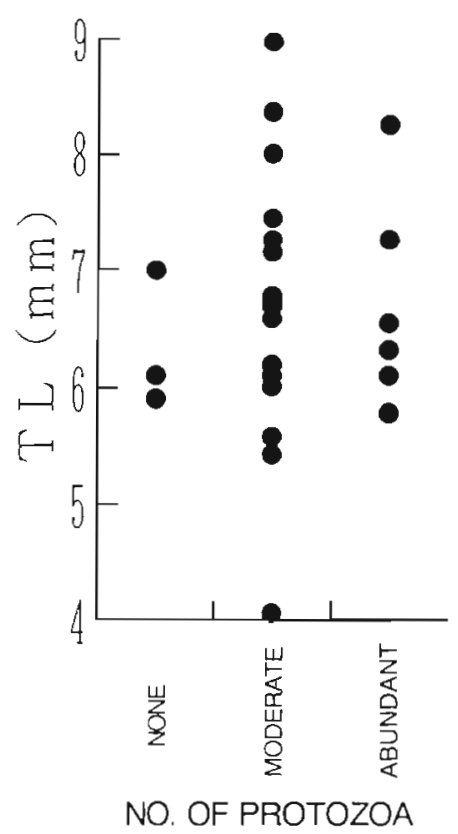

Fig. 4. Upeneus bensassi. Relationship between the numbers of protozoa in the gut and total length (TL) of larvae. None: no protozoa observed; moderate: containing less than 30 protozoa; abundant: containing more than 30
(Stns T1, T2, T3) and Iyo-Nada (Stns L1-8 and L5-5) simultaneously with the sampling of fish larvae, although ciliate densities were not measured. The

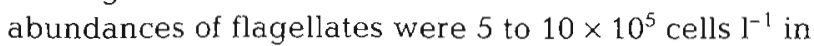
Tosa Bay and 1 to $5 \times 10^{5}$ cells $1^{-1}$ in Iyo-Nada. The maximal abundances were usually obtained in the surface layer, and there was no relationship between the amount of protozoa in the gut contents of larvae and abundances of flagellates in the ambient seawater.

On the basis of the numbers of protozoa observed in the gut, fish species were classified into 3 groups (Table 3). The first group includes taxa of larvae containing more than 30 protists in their gut (and is referred to as the 'abundant' group). Considering only species for which a minimum of 10 individuals were obtained in the field sampling, the 'abundant' group included Chelon sp., Exocoetidae spp., Carangidae spp., Mullidae spp., Girella spp., Terapon jarbua, Blenniidae spp. and Callionymidae spp. The second group is composed of larvae containing up to 30 protozoa (referred to as 'moderate'). The main species in this group are: Scorpaenidae spp., Sillago japonica, Chromis notata notata and Gobiidae spp. The third group includes larvae in which protists were absent in the gut contents of all individuals (referred to as 'none'). In this category, Engraulis japonicus and terms of biomass was roughly equivalent to the other items of the diet. Other species, e.g. Sillago japonica, also evidenced protozoan cells in their gut contents; however, the numbers of protists in a single individual did not exceed 30 and some individuals had no protists. On the other hand, in species such as Engraulis japonicus all larvae examined were completely devoid of protozoan cells in their gut contents. Table 2 lists the 52 different taxonomical groups of larvae observed, the total numbers of larval individuals examined, and the numbers of larvae classified in the 4 categories $(0,+,++,++)$. Total lengths and upper jaw lengths are also shown in Table 2. Fig. 4 illustrates the relationship between the numbers of protists in the gut and the TL of Upeneus bensassi samples. There was no significant relationship between the two, nor with the UJL of fish larvae. However, the amount of protozoa ingested was dependent on the taxon of fish larvae (Table 2).

We determined the abundances of heterotrophic flagellates in Tosa Bay
Table 3. Classification of the taxonomical groups of fish larvae on the basis of the amount of protists in the gut contents. Abundant: containing more than 30 protists in 1 individual; moderate: containing up to 30 protists in 1 individual; none: no protists observed

\begin{tabular}{|c|c|c|}
\hline \multicolumn{3}{|c|}{$\begin{array}{l}\text { Amount of protists in the gut content } \\
\text { Moderate }\end{array}$} \\
\hline $\begin{array}{l}\text { Laemonema nana } \\
\text { Chelon sp. } \\
\text { Exocoetidae spp. } \\
\text { Carangidae spp. } \\
\text { Seriola sp. } \\
\text { Sparus sarba } \\
\text { Sciaenidae sp. } \\
\text { Mullidae spp. } \\
\text { Girella spp. } \\
\text { Microcanthus strigatus } \\
\text { Terapon jarbua } \\
\text { Pomacentridae sp. } \\
\text { Blenniidae spp. } \\
\text { Parablennius yatabei } \\
\text { Callionymidae spp. } \\
\text { Scomber japonicus } \\
\text { Rudanius ercodes } \\
\text { Stephanolepis cirrhifer }\end{array}$ & $\begin{array}{l}\text { Etrumeus teres } \\
\text { Saurida sp. } \\
\text { Myctophidae spp. } \\
\text { Bregmacerotidae sp. } \\
\text { Mugil cephalus cephalus } \\
\text { Cololabis saira } \\
\text { Macroramphosus scolopax } \\
\text { Scorpaenidae spp. } \\
\text { Sebastiscus marmoratus } \\
\text { Platycephalidae sp. } \\
\text { Sacura margaritacea } \\
\text { Sillago japonica } \\
\text { Trachurus japonicus } \\
\text { Acanthopagrus schlegeli } \\
\text { Terapontidae sp. } \\
\text { Chromis notata notata } \\
\text { Labridae spp. } \\
\text { Champsodon snyderi } \\
\text { Enneapterygius etheostomu } \\
\text { Gobiidae spp. } \\
\text { Sphyraena sp. } \\
\text { Trichiurus japonicus } \\
\text { Bothidae sp. } \\
\text { Cynoglossidae sp. } \\
\text { Cynoglossus sp. }\end{array}$ & $\begin{array}{l}\text { Engraulis japonicus } \\
\text { Sardinella zunasi } \\
\text { Sardinops melanostictus } \\
\text { Ophidiidae sp. } \\
\text { Atherinidae sp. } \\
\text { Gerres oyena } \\
\text { Pinguipedidae sp. } \\
\text { Trichonotidae sp. } \\
\text { Sphyraena pinguis }\end{array}$ \\
\hline
\end{tabular}


Table 4. Total number of fish taxa and number and percent of Acanthopterygii according to abundance categories of protists in the gut. Abundant: containing more than 30 protists in 1 individual; moderate: containing up to 30 protists in 1 individual; none: no protists observed

\begin{tabular}{|lccc|}
\hline & \multicolumn{4}{c|}{ Amount of protists in the gut } \\
& Abundant & Moderate & None \\
\hline Total no. of fish taxa & 18 & 28 & 10 \\
No. of Acanthopterygii & 17 & 25 & 5 \\
\% of Acanthopterygii & 94.4 & 89.3 & 50.0 \\
\hline
\end{tabular}

Sardinops melanostictus are of particular note as no protozoa at all were observed in their gut contents, although many individuals, 23 for the former and 89 for the latter, were examined (Table 2).

Table 4 shows the percentages of Acanthopterygii according to the 3 categories of fish larvae mentioned above (Table 3). It is shown that the proportion of Acanthopterygii is largest $(94.4 \%)$ in the category with high protozoan predation ('abundant'), and lowest $(50.0 \%)$ in the 'none' group.

\section{DISCUSSION}

In the present study, we examined the gut contents of more than 400 individual fish larvae belonging to 52 different taxonomical groups. Samples were collected from 6 different stations (Fig. 1) in various seasons Abundant protist-like cells were recognized, under epifluorescence microscopy, in the gut of fish larvae. As mentioned in 'Materials and methods', these cells had clear nuclei and were easily distinguished from those of fish intestine (Figs. $2 \& 3$ ), and it can be concluded that these 'protist-like' cells were really flagellates and ciliates. There is little information on the predation of protozoa by fish larvae, except for the loricate tintinnids (Last 1978a, b, Govoni et al. 1983, Stoecker \& Govoni 1984, lkewaki \& Tanaka 1993). As non-loricate and naked protist cells are too fragile, small and transparent to be identified under light microscopy, they have not been observed or reported before.

From the results obtained in the present study, fish larvae seem to be important predators of protozoan zooplankton (Stoecker \& Capuzzo 1990). Some individuals with a TL of 5 to $7 \mathrm{~mm}$ had more than 60 protists in their gut contents (Tables $1 \& 2$ ). The amount of protozoa in the gut was only dependent on the fish species and not on morphological characteristics, such as body or mouth size (Fig. 4, Tables $1 \& 2$ ). This suggests that some fish larvae preyed on protozoa selectively among various diet items. In the present study, we did not deal with the taxonomy of protozoa preyed upon by these fish larvae; this remains open to future study.

The percentage of Acanthopteryqii was highest in the category with high protozoan predation ('abundant') (Table 4). So far, we do not have any reasonable explanation for this result. The Acanthopterygii are more highly evolved than other fish taxonomical groups (Helfman et al. 1997). They are able to swim easily (Helfman et al. 1997) and may therefore have some advantage over other groups for catching and preying on protozoa. Further studies are necessary to elucidate this point.

In our findings, none of the observed individuals of Engraulis japonicus and Sardinops melanostictus had protists in their guts (Table 2). These results suggest that the 2 species rarely prey on protists. However, Yamashita (1990) mentioned that anchovy larvae often defecate gut contents when stressed, due to their undifferentiated and straight intestine. Therefore, it is possible that individuals of Engraulis japonicus and Sardinops melanostictus were stressed during collection and may have lost their gut contents.

In the present study, it was shown that fish larvae play an important role as predators of protozoan zooplankton. This indicates that one of the links between the microbial loop and higher trophic levels may be represented by the activities of young fish larvae. Our findings provide some information on the energy flow from the microbial loop to the traditional grazing food chain (Sherr et al. 1986, Stoecker \& Capuzzo 1990).

Acknowledgements. The authors are indebted to Dr H. Morimoto, Nansei Regional Fisheries Research Institute, and the officers and crew of RV 'Toyoshio-Maru', Hiroshima University, for their help in collecting samples. Gratitude is extended to Dr Y Ozeki, National Research Institute of Fisheries Science, for his valuable comments on the manuscript. We also thank 4 anonymous reviewers for their helpful advice and criticism of the manuscript. This work was supported by a grant (04806026) from Monbusho, (the Japanese government's Ministry of Education, Science, Sports and Culture).

\section{LITERATURE CITED}

Azam F, Fenchel T, Field JG, Gray JS, Meyer-Reil LA, Thingstad $F$ (1983) The ecological role of water-column microbes in the sea. Mar Ecol Prog Ser 10:257-263

Fenchel T (1982) Ecology of heterotrophic microflagellates. IV Quantitative occurrence and importance as bacterial consumers. Mar Ecol Prog Ser 9:35-42

Fenchel T (1986) The ecology of heterotrophic microflagellates. In: Marshall KC (ed) Advances in microbial ecology, Vol 9. Plenum Press, New York, p 57-97

Fukami K, Meier B, Overbeck J (1991) Vertical and temporal changes in bacterial production and its consumption by heterotrophic nanoflagellates in a north German eutrophic lake. Arch Hydrobiol 122:129-145

Fukami K, Murata N, Morio Y, Nishijima T (1.996) Distribution of heterotrophic nanoflagellates and their importance as 
the bacterial consumer in a eutrophic seawater. J Oceanogr 52:399-407

Govoni JJ, Hoss DE, Chester A.J (1983) Comparative feeding of three species of larval fishes in the northern Gulf of Mexico: Brevoortia patronus, Leiostomus xanthurus, and Micropogonias undulatus. Mar Ecol Prog Ser 13: $189-199$

Hagström Å, Azam F, Andersson A, Wikner J, Rassoulzadegan F (1988) Microbial loop in an oligotrophic pelagic marine ecosystem: possible roles of cyanobacteria and nanoflagellates in the organic fluxes. Mar Ecol Prog Ser 49:171-178

Hartmann HJ, Taleb H, Aleya L, Lair N (1993) Predation on ciliates by the suspension-feeding calanoid copepod Acanthodiaptomus denticornis. Can J Fish Aquat Sci 50: $1382-1393$

Helfman GS, Collette BB, Facey DE (1997) Teleosts at last, II Spiny-rayed fishes. In: Helfman GS, Collette BB, Facey D $E$ (eds) The diversity of fishes. Blackwell Science, Nalden, MA, p 244-270

Ikewaki Y, Tanaka M (1993) Feeding habitats of Japanese flounder (Paralichthys olivaceus) larvae in the western part of Wakasa Bay, the Japan Sea. Nippon Suisan Gakkaishi 59:951-956

Imai I, Itoh K (1984) Distribution of heterotrophic microflagellates in Suo-Nada, western Seto Inland Sea, in May 1983. Bull Nansei Reg Fish Res Lab 17:219-233 (in Japanese with English abstract)

Lasker R, Feder HM, Theilacker GH, May RC (1970) Feeding, growth, and survival of Engraulis mordax larvae reared in the laboratory. Mar Biol 5:345-353

Last JM (1978a) The food of four species of pleuronectiform larvae in the eastern English Channel and southern North Sea. Mar Biol 45:359-368

Last JM (1978b) The food of three species of gadoid larvae in the eastern English Channel and southern North Sea. Mar Biol 48:377-386

Nakata K (1988) Alimentary tract contents and feeding conditions of ocean-caught post larval Japanese sardine, Sardinops melanostictus, Bull Tokai Reg Fish Res Lab 126 : $11-24$

Editorial responsibility: Fereidoun Rassoulzadegan (Contributing Editor), Villefrance-sur-Mer, France
Porter KG, Feig YS (1980) The use of DAPI for identifying and counting aquatic microflora. Limnol Oceanogr 25:943-948

Porter KG, Sherr EB, Sherr BF, Pace M. Sanders RW (1985) Protozoa in planktonic food webs. J Protozool 32:409-41.5

Sherr E, Sherr B (1988) Role of microbes in pelagic food webs: a revised concept. Limnol Oceanogr 33:1225-1227

Sherr EB, Sherr BF, Paffenhöfer GA (1986) Phagotrophic protozoa as food for metazoans: a 'missing' trophic link in marine pelagic food webs? Mar Microb Food Webs 1:61-80

Stoecker DK, Capuzzo JM (1990) Predation on Protozoa: its importance to zooplankton. J Plankton Res 12:891-908

Stoecker DK, Govoni JJ (1984) Food selection by young larval gulf menhaden (Brevootia patronus). Mar Biol 80:299-306

Stoecker DK, Michaels AE, Davis LH (1987a) Grazing by jellyfish, Aurelia aurelia, on microzooplankton. J Plankton Res 9:901-915

Stoecker DK, Verity PG, Michaels AE, Davis LH (1987b) Feeding by larval and post-larval ctenophores on microzooplankton. J Plankton Res 9:667-683

Tanaka $M$ (1980) Feeding and survival in marine fish larvae. 1. Food organisms of wild larvae. Aquabiology, Tokyo 2 440-447 (in Japanese with English abstract)

Turner JT, Tester PA, Ferguson RL (1988) The marine cladoceran Penilia avirostris and the 'microbial loop' of pelagic food webs. Limnol Oceanogr 33:245-255

Uye S, Shimazu T (1997) Geographical and seasonal variations in abundance, biomass and estimated production rates of meso- and macrozooplankton in the Inland Sea of Japan. J Oceanogr 53:529-538

Uye S, Nagano N, Tamaki H (1996) Geographical and seasonal variations in abundance, biomass and estimated production rates of microzooplankton in the Inland Sea of Japan. J Oceanogr 52:689-703

Uye S, Nagano N, Shimazu T (1998) Biomass, production and trophic roles of micro- and net-zooplankton in Dokai Inlet, a heavily eutrophic inlet, in summer. Plankton Biol Ecol 45:171-182

Yamashita Y (1990) Defecation of larval Japanese anchovy (Engraulis japonica) during net sampling. Bull Tohoku Natl Fish Res Inst 52:29-32 (in Japanese with English abstract)

Submitted: January 20, 1999; Accepted: April 7, 1999

Proofs received from author(s): August 5, 1999 